\title{
Rancang Bangun Bahan Ajar Siswa Diskalkulia Sekolah Dasar
}

\author{
Abdul Karim ${ }^{1}$, Indah Mayang Purnama ${ }^{2 *)}$, \& Yogi Wiratomo ${ }^{3}$ \\ ${ }^{1,2,3}$ Universitas Indraprasta PGRI Jakarta
}

\section{INFO ARTICLES}

Article History:

Received: 03-05-2020

Revised: 22-06-2020

Approved: 25-06-2020

Publish Online: 27-06-2020

\section{KeyWords:}

design, scalable, Elementary school

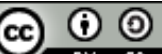

This article is licensed under a Creative Commons AttributionShareAlike 4.0 International License.

\begin{abstract}
This research aims to design learning media as a solution for mathematics learning that requires innovative teaching materials so as to minimize learning disorder. The implementation of this teaching materials using the instructional development Model (MPI) which has three phases: 1) performs analysis and observation of the students ' behaviour and characteristics; 2) Develop a prototype of student learning media; 3) Formative evaluation. In this research is still in the stage of analysis and development of prototype systems. The results of the development in the form of mathematical learning modules for Elementary school Class $V$ for patients with diskalkulia. The characteristics of the modules, containing the problems of daily life, using simple sentences, color combinations that can facilitate the students in the process of learning in progress, and in accordance with the general instructional objectives (TIU) and problem solving mathematically.
\end{abstract}

\begin{abstract}
Abstrak: Penelitian ini bertujuan merancang media pembelajaran sebagai solusi atas pembelajaran matematika yang membutuhkan bahan ajar inovatif sehingga dapat meminimalisasi gangguan belajar. Pelaksanaan pengembangan bahan ajar ini menggunakan Model Pengembangan Instruksional (MPI) yang memiliki 3 tahapan: 1) melakukan analisis dan observasi perilaku dan karakteristik siswa; 2) mengembangkan prototipe media pembelajaran siswa; 3 ) evaluasi formatif. Dalam penelitian ini masih dalam tahap analisis dan pengembangan prototipe sistem. Hasil pengembangan berupa modul pemelajaran matematika untuk SD Kelas V bagi penderita diskalkulia. Karakteristik modul, berisi permasalahan kehidupan sehari-hari, menggunakan kalimat sederhana, perpaduan warna yang dapat mempermudah siswa dalam proses belajar mengajar berlangsung, serta sesuai dengan Tujuan Instruksional Umum (TIU) dan pemecahan masalah matematis.
\end{abstract}

Correspondence Address: Jl. Raya Tengah No. 80, Kel. Gedong, Kec. Pasar Rebo, Jakarta Timur, Kode Pos: 13760, Indonesia; e-mail: indahmayang016@gmail.com

How to Cite (APA $6^{\text {th }}$ Style): Karim, A., Purnama, I.M., \& Wiratomo, Y. (2020). Rancang Bangun Bahan Ajar Siswa Diskalkulia Sekolah Dasar. JKPM (Jurnal Kajian Pendidikan Matematika), 5(2): 273-288.

Copyright: Karim, A., Purnama, I.M., \& Wiratomo, Y. (2020)

Competing Interests Disclosures: The authors declare that they have no significant competing financial, professional or personal interests that might have influenced the performance or presentation of the work described in this manuscript. 


\section{PENDAHULUAN}

Dalam dunia pendidikan, mata pelajaran matematika sudah diajarkan dari taman kanak-kanak hingga perguruan tinggi. Tentu saja di setiap jenjang pendidikan akan disesuaikan tingkat kesulitan dan tujuan pembelajaran matematika itu sendiri. Tujuan pembelajaran matematika yang tertuang dalam Permendiknas No 22 tahun 2006 tentang standar isi yaitu: "(1) memahami konsep matematika, menjelaskan keterkaitan antar konsep dan mengaplikasikan konsep atau algoritma secara luwes, akurat, efisien, dan tepat dalam pemecahan masalah; (2) menggunakan penalaran pada pola dan sifat, melakukan manipulasi matematika dalam membuat generalisasi, menyusun bukti atau menjelaskan gagasan dan pernyataan matematika; (3) memecahkan masalah yang meliputi kemampuan memahami masalah, marancang model matematika, menyelesaikan model dan menafsirkan solusi yang diperoleh; (4) mengkomunikasikan gagasan dengan simbol, tabel, diagram, atau media lain untuk memperjelas keadaan atau masalah; (5) memiliki sikap menghargai kegunaan matematika dalam kehidupan, yaitu memiliki rasa ingin tahu, perhatian, dan minat dalam mempelajari matematika serta sikap ulet dan percaya diri dalam pemecahan masalah. Berdasarkan tujuan tersebut pemerintah telah melakukan pembaruan dan usaha untuk melakukan perbaikan pada sistem pendidikan, seperti penyempurnaan kurikulum dan meningkatkan kemampuan pengajar melalui penataran. Meskipun demikian, hasil belajar siswa masih rendah khususnya pada pelajaran matematika. Faktanya (Okezone, 2018), Kemendikbud melalui program Indonesia Nasional Assessment Program (INAP), pada tahun 2016 menunjukkan sekitar 77,13\% siswa sekolah dasar di seluruh Indonesia memiliki kompetensi matematika yang sangat rendah, yakni $20,58 \%$ cukup dan hanya 2,29\% yang kategori baik. Hal ini merupakan tantangan bagi guru untuk meningkatkan kompetensi matematika yang rendah. Diantara banyak hal alternatif solusi yang dapat dilakukan guru dalam upaya peningkatan kualitas proses pembelajaran sekaligus sebagai upaya peningkatan hasil belajar siswa, khususnya dalam pembelajaran matematika, guru harus dapat terus berkreasi menampilkan hal-hal yang dianggap baru bagi diri siswa di ruang kelas (Nadiyah, 2019).

Salah satu masalah yang sering ditemukan di sekolah dasar adalah masalah gangguan belajar. Masalah ini biasa muncul di sekolah maupun di luar sekolah. Berdasar pada hasil penelitian Kaufmann, 2003; Shalev, 2004 (dalam Santrock, 2009: 248), para peneliti menemukan bahwa 'siswa yang memiliki kesulitan dalam perhitungan matematika sering mempunyai kekurangan neuropsikologis dan kognitif, termasuk prestasi yang buruk dalam mengelola ingatan, persepsi visual, dan kemampuan visual-spasial'. Menurut Geary (dalam Azhari, 2017), 'pada umumnya 5\% dan $8 \%$ dari usia anak sekolah mengalami gangguan belajar (diskalkulia), siswa dengan gangguan lemah memori atau defisit kognitif mengalami gangguan dalam pempelajari konsep atau prosedur matematika'.

Siswa yang memiliki gangguan dalam pembelajaran biasanya akan menghadapi kesulitan dalam proses pembelajaran seperti hilangnya konsentrasi, cepat lupa, sulit membaca, menulis dan berhitung. Sejalan dengan pendapat tersebut, Sudha dan Shalini (dalam Firda, 2019) mengemukakan 'diskalkulia merupakan istilah luas untuk kesulitan dalam belajar matematika'. Hal ini mencakup semua jenis permasalahan dalam matematika seperti ketidakmampuan untuk memahami arti bilangan sampai dengan ketidakmampuan menerapkan prinsip matematika dalam memecahkan masalah.

Suatu keadaan dari gangguan pembelajaran merupakan perwujudan dari lemahnya kemampuan pemecahan masalah siswa yang dikatakan belum matang. Sehingga, siswa yang mengalami gangguan pembelajaran tidak belajar fakta mengenai konsep-konsep berhitung atau mengenali simbol-simbol 
aritmatika (tambah, kurang, kali, bagi) dikarenakan tidak dapat mengingat dengan lancar dari memorinya. Hal ini sesuai dengan pendapat Price dan Anasari (dalam Azhari, 2017) "Akibat yang wajar dari pengambilan fakta mengenai perkembangan gangguan diskalkulia adalah penggunaan strategi pemecahan masalah yang tidak efisien atau belum matang." Jika seorang anak dengan perkembangan gangguan diskalkulia belum belajar fakta aritmatika tertentu, dan karenanya tidak dapat mengingatnya dengan lancar dari ingatan, ia akan menggunakan strategi prosedural, yang seringkali kurang optimal dan terlalu melelahkan.

Siswa dengan gangguan matematika memiliki kesulitan yang membuat terhambatnya kemajuan pembelajaran di sekolah. Menurut Subini (2012) terdapat dua faktor penyebab seorang siswa kesulitan dalam belajar matematika yaitu: 1) faktor internal pada diri siswa itu sendiri seperti daya ingat, terganggunya alat indra, usia anak, jenis kelamin, kebiasaan belajar tingkat kecerdasan, minat, emosi dan lain-lain; 2) faktor eksternal pada diri siswa terbagi tiga yakni faktor keluarga, faktor sekolah dan faktor lingkungan masyarakat. Berdasarkan pendapat di atas faktor di sekolah merupakan salah satu yang mempengaruhi kesulitan belajar dikarenakan metode pembelajaran cenderung menggunakan metode ceramah dan penugasan. Faktor eksternal ini terjadi karena kurangnya media pembelajaran yang mendukung seperti alat peraga dan modul. Ketidaktepatan dalam penentuan strategi dan penyampaian materi pembelajaran memperburuk kondisi siswa. Hal ini berdampak pada siswa yang merasa jenuh, tidak bersemangat, dan akhirnya kurang berprestasi.

Siswa dengan gangguan kesulitan belajar matematika mungkin mengalami ketelambatan dalam perkembangan kognitifnya, keterlambatan dalam memahami informasi yang sudah dipahami dengan informasi yang baru yang diajarkan oleh guru. Hal-hal yang mungkin terjadi pada siswa yang mengalami kesulitan pembelajaran matematika mengenai hubungan operasi hitung seperti perkalian dengan pembagian, pengurangan dengan penjumlahan bahkan mengkonversi pecahan menjadi desimal. Tidak hanya itu kesulitan seorang siswa dalam memahami soal cerita dan pemahaman mengenai sistem ordinal dan kardinal merupakan bagian dari kesulitan pembelajaran matematika. Hal ini sesuai dengan pendapat Subini (2012) kesulitan berhitung dibagi menjadi dua kelompok, yaitu: 1) Siswa tidak memiliki kemampuan dasar berhitung seperti mengelompokkan, membandingkan, mengurutkan, menyimbolkan dan mengkonversi; 2) Siswa tidak memiliki kemampuan untuk menetukan nilai tempat; 3) Siswa tidak memiliki kemampuan dalam melakukan operasi penjumlahan dan pengurangan; dan 4) Siswa tidak memiliki kemampuan dalam melakukan operasi perkalian dan pembagian. Terkait permasalahan di atas, merujuk hasil penelitian Nadun (2017), guru sebagai praktisi pendidikan dituntut untuk berupaya mengembangkan, memilih, dan menggunakan berbagai alat terkait dengan teknologi pembelajaran serta mampu menggunakan teknologi elektronik dan komunikasi untuk menyampaikan ilmunya kepada siswa, khususnya pada mata pelajaran matematika.

Dalam penelitian Patricia dan Zamzam (2019), dijabarkan beberapa jenis diskalkulia yang ada pada siswa, dan hasil temuan penelitiannya adalah beberapa siswa laki-laki dan perempuan mengalami diskalkulia jenis proctagnostig dan diskalkulia indiagnostikk yaitu kesulitan dalam membandingkan bilangan yang memiliki nilai lebih besar dan sebaliknya, dan kesulitan untuk mengingat konsep operasi bilangan yang sudah dipelajari. Guru dalam pembelajaran matematika, hendaknya menggunakan sesuatu yang konkret, mudah dipahami, menggunakan contoh-contoh yang sederhana, menggunakan bahasa yang mudah dipahami dan dilengkapi dengan alat peraga, dilakukan dalam situasi yang menarik dan menyenangkan, tentunya hal ini dapat memotivasi siswa untuk lebih memahami apa yang diajarkan oleh guru. Berdasarkan hasil dari penelitian penelitian sebelumnya yang menunjukkan bahwasanya ada beberapa siswa yang mengalami kesulitan belajar matematika (diskalkulia) maka kami tertarik untuk melaukan penelitian serupa tetapi dengan fokus yang berbeda yaitu jika penelitian-penelitian sebelumnya membahas jenis-jenis diskalkulia yang dialami oleh siswa 
maka kami menawarkan solusi-solusi dari apa yang dibutuhkan oleh siswa yang mengalami gangguan belajar matematika (diskalkulia) dengan mengembangkan media pembelajaran yang dapat digunakan sebagai media pembelajaran yang efektif dan efisien. Sebuah bahan ajar yang mudah diperbanyak dan tidak membebankan siswa. Penggunaan bahan ajar yang dikembangkan merupakan ragam bentuk pembelajaran di kelas. Sehingga proses pembelajaran akan lebih bervariasi dari segi strategi, penggunaan bahan ajar, metode dan model pembelajaran. Harapannya pembelajaran matematika tidak lagi membosankan dan terasa sulit.

\section{METODE}

Penelitian dilaksanakan dengan membuat analisis kebutuhan dan uji coba penelitian beberapa sekolah dasar di Kecamatan Muara Gembong Kabupaten Bekasi. Waktu penelitian dilaksanakan selama 5 bulan dari Bulan September 2019 sampai dengan Januari 2020. Subjek dalam penelitian ini adalah bahan pembelajaran matematika yang dikembangkan dalam bentuk modul untuk digunakan pada siswa yang mengalami gangguan kesulitan pembelajaran matematika (diskalkulia).

Jenis penelitian ini merupakan penelitian pengembangan. Produk yang dikembangkan berupa bahan instruksional dan desain modul pada pembelajaran Matematika SD Kelas V. Prosedur penelitian ini mengacu pada Model Pengembangan Instruksional (MPI) oleh Suparman (2014: 126) yang terdiri dari tiga tahap, sebagai berikut:

1. Tahap Pertama: definisi, terdiri dari dua langkah, sebagai berikut:

a. Melakukan analisis instruksional;

b. Mengidentifikasi perilaku dan karakteristik awal siswa.

2. Tahap Kedua: analisis dan pengembangan prototipe sistem, terdiri dari empat langkah sebagai berikut:

a. Menulis tujuan instruksional khusus;

b. Menyusun alat penilaian hasil belajar;

c. Menyusun strategi instruksional;

d. Mengembangkan bahan instruksional.

3. Tahap Ketiga: melaksanakan evaluasi formatif

a. Penelaahan oleh pakar dan revisi;

b. Evaluasi oleh 1-3 siswa dan revisi;

c. Uji coba dalam skala terbatas yang melibatkan sekelompok kecil siswa, guru dan sarana penunjang diikuti dengan revisi;

d. Uji coba lapangan seperti keadaan yang sebenarnya dengan melibatkan semua komponen dalam sistem sesungguhnya.

Pada prosedur penelitian ini peneliti baru melaksanakan pada tahap kedua analisis dan pengembangan prototipe sistem. 


\section{HASIL}

Pada tahapan penelitian pengembangan ini produk yang dihasilkan adalah rancang bangun bahan pembelajaran dalam bentuk modul untuk siswa dengan gangguan belajar diskalkulia pada Sekolah Dasar Kelas V, bahasan yang dirancang berisikan permasalahan dalam kehidupan seharihari yang berhubungan dengan matematika sekaligus pengunaan kalimat dan perpaduan warna yang dapat digunakan untuk memfasilitasi siswa dalam pembelajaran matematika sesuai dengan Tujuan Instruksional Umum (TIU) serta pemecahan masalah matematis.

Produk bahan instruksional ini mencakup materi yang tercantum dalam Tujuan Instruksional Khusus (TIK) untuk keseluruhan materi pembelajaran matematika Sekolah Dasar Kelas V serta penggunaannya dalam pemecahan masalah sehari-hari. Bahan instruksional ini terdiri atas 8 (delapan) BAB, yaitu: pecahan; FPB dan KPK; perbandingan, skala, jarak dan waktu; sudut; bilangan pangkat dan akar bilangan; bangun datar; bangun ruang; statistika.

Dalam setiap pembuka materi ditunjang dengan gambar, peta konsep dan perpaduan warna yang dipadukan dengan materi. Setiap bab terdapat penjelasan materi berupa deskripsi singkat dan berbagai contoh soal latihan yang akan mendukung dan menambah pemahaman siswa, modul ini didukung dengan penggunaan bahasa yang mudah dipahami dan pemberian contoh soal yang beragam, adapula potensi diri sebagai latihan siswa. Selain itu, setiap halaman akhir materi dilengkapi dengan evaluasi materi.

Sebelum menyusun bahan instruksional pembelajaran terdapat beberapa proses yang dilalui seperti menganalisis kebutuhan instruksional, menentukan tujuan instruksional, melakukan analisis instruksional, mengidentifikasi perilaku dan karateristik siswa, menentukan tujuan instruksional khusus, menyusun alat hasil belajar, penyusunan hasil analisis, penyusunan laporan hingga mengembangkan bahan instruksional. Berikut penjabaran proses pengembangan bahan instruksional. 1. Analisis Kebutuhan Intruksional

Proses analisis ini bertujuan untuk mengetahui alasan apa yang melatarbelakangi peneliti untuk mengembangkan sebuah desain pembelajaran. Dengan kata lain, sebuah desain instruksional dikembangkan karena ada keluhan atau kekurangan atas desain pembelajaran sebelumnya. Pembelajaran yang akan didesain saat ini adalah pembelajaran Matematika yang diberikan kepada siswa Kelas V Sekolah Dasar untuk mengatasi gangguan diskalkulia pada pembelajaran matematika.

Tabel 1. Identitas Kebutuhan untuk Menentukan Tujuan Instruksional

\begin{tabular}{|c|c|c|c|}
\hline $\begin{array}{c}\text { Karakteristik } \\
\text { Umum anak Kelas } \\
\text { V SD }\end{array}$ & $\begin{array}{c}\text { Sikap/perilaku anak } \\
\text { Kelas V SD saat } \\
\text { menerima pelajaran } \\
\text { matematika }\end{array}$ & $\begin{array}{c}\text { Masalah kesulitan } \\
\text { memahami materi } \\
\text { matematika pada siswa } \\
\text { keas V }\end{array}$ & Sumber \\
\hline $\begin{array}{l}\text { 1. Aktif } \\
\text { 2. Cenderung } \\
\text { pemalu namun } \\
\text { memiliki rasa } \\
\text { ingin tahu yang } \\
\text { tinggi }\end{array}$ & $\begin{array}{l}\text { 1. Pemalu } \\
\text { 2. Belum ada kesadaran } \\
\text { diri untuk disiplin dan } \\
\text { belum bisa } \\
\text { bertanggungjawab } \\
\text { terhadap tugas } \\
\text { 3. Belum fokus karena } \\
\text { suka mengobrol dan } \\
\text { bercanda ketika materi } \\
\text { disampaikan guru. }\end{array}$ & $\begin{array}{l}\text { 1. KPK dan FPB } \\
\text { 2. Sulit berkonsentrasi }\end{array}$ & $\begin{array}{c}\text { Responden 1, } \\
\text { Guru SD Kelas } \\
\text { V di Kecamatan } \\
\text { Muara } \\
\text { Gembong }\end{array}$ \\
\hline
\end{tabular}




\begin{tabular}{|c|c|c|c|}
\hline $\begin{array}{c}\text { Karakteristik } \\
\text { Umum anak Kelas } \\
\text { V SD }\end{array}$ & $\begin{array}{l}\text { Sikap/perilaku anak } \\
\text { Kelas V SD saat } \\
\text { menerima pelajaran } \\
\text { matematika }\end{array}$ & $\begin{array}{c}\text { Masalah kesulitan } \\
\text { memahami materi } \\
\text { matematika pada siswa } \\
\text { keas V }\end{array}$ & Sumber \\
\hline $\begin{array}{l}\text { 1. Antusiasme } \\
\text { belajar tinggi } \\
\text { 2. Senang } \\
\text { mencoba coba } \\
\text { 3. Belum mandiri } \\
\text { 1. Malu untuk } \\
\text { bertanya. } \\
\text { 2. Belum mandiri } \\
\text { 3. Sulit diatur } \\
\text { 4. Malas membaca }\end{array}$ & $\begin{array}{l}\text { 1. Siswa bersikap baik } \\
\text { namun masih ada } \\
\text { beberapa yang masih } \\
\text { kekanak-kanakan } \\
\text { 2. Antusias } \\
\text { 1. Kurang motivasi } \\
\text { belajar. } \\
\text { 2. Beberapa siswa sudah } \\
\text { mulai aktif dan } \\
\text { beberapa siswa masih } \\
\text { ada yang pemalu } \\
\text { dalam menyampaikan } \\
\text { pendapat } \\
\text { 3. Sulit diatur }\end{array}$ & $\begin{array}{l}\text { 1. Pada materi kecepatan } \\
\text { dan debit (karena untuk } \\
\text { materi ini masih sangat } \\
\text { baru) belum pernah } \\
\text { mereka temui }\end{array}$ & $\begin{array}{c}\text { Responden 2, } \\
\text { Guru SD Kelas } \\
\text { V di Kecamatan } \\
\text { Muara } \\
\text { Gembong } \\
\text { Responden 3, } \\
\text { Guru SD Kelas } \\
\text { V di Kecamatan } \\
\text { Muara } \\
\text { Gembong }\end{array}$ \\
\hline
\end{tabular}

Sumber: Data Penelitian yang Diolah

Dari beberapa pendapat yang tercantum pada Tabel 1 dapat diambil simpulan sebagai berikut:

a. Karakteristik Umum Siswa Kelas V

Pada umumnya, siswa sekolah SD Kelas V masih pemalu dan belum mandiri, namun ada beberapa siswa yang memiliki rasa ingin tahu dan antusias untuk belajar. Dari pengamatan yang dilakukan selama melakukan analisis kebutuhan, peneliti menyimpulkan karakter siswa SD Kelas V masih pemalu dan belum mandiri.

b. Sikap Perilaku Siswa saat Menerima Pelajaran Matematika

Perilaku siswa sekolah dasar Kelas V saat menerima pelajaran kurang fokus dan mencari perhatian lain pada saat guru menerangkan materi. Ada beberapa siswa yang sulit memahami pembelajaran matematika hal ini disebabkan karena kesulitan dalam memahami matematika dan kurangnya pemahaman konsep matematika.

c. Masalah atau Kesulitan Memahami Materi pada Siswa SD Kelas V

Dari pendapat berbagai narasumber yang diperoleh dari angket dan wawancara, ada beberapa siswa siswa SD Kelas V kesulitan memahami materi Matematika karena kesulitan memahami konsep matematika dan memahami simbol simbol matematika dalam operasi hitung, contoh kesulitannya kesulitan memahami pada materi KPK dan FPB, pecahan, kecepatan dan debit.

2. Tujuan Instuksional Umum

Berdasarkan analisis kebutuhan, didapatkan beberapa siswa kesulitan dalam memahami matematika hal ini disebabkan oleh kesulitan memahami konsep matematika dan memahami simbol simbol matematika, maka peneliti menduga ada kemungkinan siswa mengalami gangguan dalam pembelajaran matematika yang disebabkan oleh gangguan diskalkulia. Maka peneliti merumuskan tujuan instruksional umum sebagai berikut: "Jika diberikan soal latihan Matematika dengan modifikasi warna dan ukuran simbol dan angka mengenai pelajaran Matematika Sekolah Dasar Kelas V, maka siswa Kelas V SD dharapkan mampu memahami dan mengerjakan dengan baik dalam menyelesaikan soal-soal latihan maupun dalam pemecahan masalah berbentuk soal cerita dengan 
kemampuan sendiri, cepat, dan minimal benar $80 \%$ meliputi materi Kelas V Sekolah Dasar serta meningkatnya antusiasme belajar, jujur, dan kreatif'.

\section{Analisis Kebutuhan}

a. Mampu memahami bentuk operasi hitung pecahan

b. Mampu memahami bentuk KPK dan FPB

c. Mampu memahami perbandingan skala, jarak, kecepatan dan waktu.

d. Mampu memahami bentuk sudut.

e. Mampu memahami bentuk bilangan pangkat dan akar bilangan.

f. Mampu memahami bentuk bangun datar.

g. Mampu memahami bentuk bangun ruang.

h. Mampu memahami materi statistika

\section{Identifikasi Perilaku dan Karakteristik Awal Siswa}

Sebelum membuat desain intruksional, diperlukan identifikasi terhadap perilaku siswa. Menurut Suparman (2014), "Perilaku dan karakteristik awal siswa sangatlah penting karena memiliki implikasi terhadap penyusunan bahan dan sistem instruksional." Atas dasar keduanya inilah nanti akan diamati dan hasil analisis sebagai dasar dalam pengembangan bahan intruksional yang sesuai untuk siswa tersebut. Masa usia siswa Kelas V SD merupakan masa peralihan seorang anak mulai menuju remaja atau lebih dikenal mereka mengalami masa pubertas. Mereka yang berifat kekanakkanakan kini mulai dapat memilih hal yang baik untuk dikerjakan dan meninggalkan hal buruk. Selain itu, mulai menunjukkan kepercayaan diri dan kesadaran diri untuk bertanggungjawab dan disiplin dalam belajar.

\section{Tujuan Instruksional Khusus}

Pentingnya menempatkan tujuan instruksional khusus sebagai komponen awal dalam mendesain instruksional merupakan pusat perhatian setiap peneliti. Menurut Suparman (2014), "Perumusan TIK merupakan titik permulaan yang sesungguhnya dari proses desain instruksional". Tujuan instruksional khusus merupakan dasar dan pedoman bagi proses selanjutnya dalam pengembangan instruksional. Perumusan TIK adalah sebagai berikut :

1. Jika diberikan tes mengenai mengidentifikasi sifat operasi hitung bilangan bulat dengan modifikasi warna dan ukuran simbol dan angka mengenai pelajaran Matematika, maka siswa Kelas V SD akan mampu menjawab dan menyelesaikan secara jelas dan terperinci, minimal benar $80 \%$.

2. Jika diberikan tes mengenai operasi hitung pecahan, dengan modifikasi warna dan ukuran simbol dan angka mengenai pelajaran Matematika maka siswa Kelas V SD akan mampu menjawab dan menyelesaikan secara jelas dan terperinci, minimal benar $80 \%$.

3. Jika diberikan tes mengenai kecepatan dan debit, dengan modifikasi warna dan ukuran simbol dan angka mengenai pelajaran Matematika maka siswa Kelas V SD akan mampu menjawab dan menyelesaikan secara jelas dan terperinci minimal benar $80 \%$.

4. Jika diberikan tes mengenai perbandingan dan skala, dengan modifikasi warna dan ukuran simbol dan angka mengenai pelajaran Matematika maka siswa Kelas V SD akan mampu menjawab dan menyelesaikan secara jelas dan terperinci, minimal benar $80 \%$. 
6. Menyusun Alat Penilaian Hasil Belajar

Alat penilaian hasil belajar merupakan sebuah keharusan yang harus disusun peneliti instruksional yang bertujuan untuk mengukur tingkat penguasaan siswa dalam setiap kompetensi pembelajaran "Setiap alat penilaian hasil belajar yang relevan dengan TIK adalah valid untuk digunakan (Suparman, 2014)". Jika setelah proses instruksional seluruh siswa ternyata menguasai $100 \%$ perilaku dalam TIK tersebut, maka dapat didefinisikan bahwa proses instruksional tersebut dianggap sudah efektif untuk digunakan.

Penyusunan alat penilaian ini dimulai dari kisi-kisi alat penilaian yang disusun yang terdiri dari delapan bab. Pada masing-masing bab memiliki tujuan instruksional, tes objektif, uraian materi, indicator soal dan bentuk soal. Berikut peneliti tampilkan satu bab penyusunan kisi-kisi alat penilaian yang peneliti susun.

Tabel 2. Format Tabel Spesifikasi Tes yang Kompeherensif untuk Mata Pelajaran Matematika Sekolah Dasar Kelas V

\begin{tabular}{|c|c|c|c|c|c|c|}
\hline \multirow{2}{*}{$\begin{array}{c}\text { Tujuan } \\
\text { Instruksional }\end{array}$} & \multirow{2}{*}{$\begin{array}{c}\text { Tes } \\
\text { Objektif }\end{array}$} & \multirow[t]{2}{*}{ Uraian Materi } & \multirow[t]{2}{*}{ Indikator Soal } & \multicolumn{3}{|c|}{ Bentuk Soal } \\
\hline & & & & PG & Esai & Kinerja \\
\hline \multirow{7}{*}{$\begin{array}{l}\text { BAB III } \\
\text { Mampu memahami } \\
\text { perbandingan skala, } \\
\text { jarak, kecepatan } \\
\text { dan waktu }\end{array}$} & $\mathrm{C} 2$ & $\begin{array}{l}\text { A. Satuan } \\
\text { iarak }\end{array}$ & $\begin{array}{l}\text { Merubah satuan } \\
\text { jara }\end{array}$ & & $\sqrt{ }$ & \\
\hline & $\mathrm{C} 2$ & $\begin{array}{l}\text { B. Satuan } \\
\text { waktu }\end{array}$ & $\begin{array}{l}\text { Menentukan } \\
\text { satuan waktu }\end{array}$ & & $\sqrt{ }$ & \\
\hline & $\mathrm{C} 2$ dan $\mathrm{C} 3$ & C. Kecepatan & $\begin{array}{l}\text { Menghitung } \\
\text { kecepatan }\end{array}$ & & $\sqrt{ }$ & \\
\hline & $\mathrm{C} 2$ & D. Skala & $\begin{array}{l}\text { 1. Penentuan } \\
\text { denah pada } \\
\text { suatu tempat }\end{array}$ & & $\sqrt{ }$ & \\
\hline & & & 2. Menghitung & & & \\
\hline & & & $\begin{array}{l}\text { skala pada } \\
\text { suatu peta }\end{array}$ & & $\sqrt{ }$ & \\
\hline & $\mathrm{C} 2$ dan $\mathrm{C} 3$ & EVALUASI B & B III & $\sqrt{ }$ & $\sqrt{ }$ & \\
\hline
\end{tabular}

Langkah-langkah yang dilakukan diawali dengan menulis butir-butir tes sesuai dengan kisikisi yang telah dibuat. Menurut Suparman (2014) terdapat dua hal-hal yang harus diperhatikan dalam menulis setiap butir tes yaitu: 1) macam dan jumlah butir tes sesuai dengan tabel spesifikasi; 2) menggunakan komponen kondisi dalam TIK sebagai dasar dalam menyusun pertanyaan. Setiap kali menyelesaikan penulisan butir tes atau satu kelompok butir tes yang mengacu pada satu TIK, peneliti instruksional harus benar-benar memikirkan dan meyakinkan pada diri sendiri bahwa siswa dapat menguasai perilaku yang dikehendaki oleh butir tes tersebut dengan benar. Proses ini merupakan kunci validasi isi suatu tes. Dari kisi-kisi yang terdapat pada tabel spesifikasi di atas, butir tes dapat disusun sebagai berikut.

TIK 3:

Jika diberikan tes mengenai perbandingan skala, jarak, kecepatan dan waktu, maka siswa Kelas V

SD akan mampu menjawab dan menyelesaikan secara jelas dan tepat, minimal benar $80 \%$.

Butir tes:

Jarak antara rumah Dimas dan taman $2 \mathrm{~km}$. Dimas naik sepeda dengan kecepatan 4 km/jam. Bila Dimas berangkat dari rumah pukul 15.00. Pukul berapa Dimas sampai di taman? 
Selanjutnya, merakit tes dengan menuliskan petunjuk menjawab tes. Penjabaran butir-butir tes di atas yang telah disusun dan sesuai dengan TIK. Selanjutnya peneliti merangkai butir-butir soal tersebut menjadi kesatuan bentuk soal yang utuh dan disertai dengan petunjuk untuk menjawab tes tersebut.

\section{Strategi Instruksional}

Dalam penyusunan strategi, peneliti menerapkan strategi pembelajaran kooperatif dengan metode-metode pembelajaran yang digunakan yaitu metode Jigsaw, TGT (Team Game Tournament), NHT (Number Head Together), dan picture and picture. Strategi pembelajaran kooperatif adalah rangkaian kegiatan kegiatan belajar yang dilakukan dalam kelompok-kelompok tertentu untuk mencapai tujuan pembelajaran yang telah dirumuskan.

Keempat strategi tersebut, peneliti pilih karena karakteristik siswa Kelas V SD yang lebih senang dengan kegiatan belajar mengajar secara berkelompok. Diharapkan supaya ada dampak pembelajaran, yaitu berupa peningkatan prestasi belajar siswa (student achievement), dan peningkatan pada dampak pendukung seperti pola pikir, kontrol emosi, proses penerimaan materi terhadap siswa, kepercayaan diri, rasa bangga, rasa hormat, norma akademik, penghargaan terhadap waktu, dan suka memberi pertolongan kepada orang lain.

Berikut adalah uraian strategi pembelajaran dalam pengembangan desain pembelajaran Matematika Sekolah Dasar Kelas V pada BAB skala, jarak kecepatan dan waktu.

Mata pelajaran: Matematika SD Kelas V

TIK No. 3 :

Jika diberikan tes mengenai perbandingan skala, jarak, kecepatan dan waktu, maka siswa Kelas V SD akan mampu menjawab dan menyelesaikan secara jelas dan tepat, minimal benar $80 \%$.

Tabel 3. Strategi Pembelajaran TIK No. 3

\begin{tabular}{|c|c|c|c|}
\hline $\begin{array}{l}\text { URUTAN KEGIATAN } \\
\text { PEMBELAJARAN }\end{array}$ & GARIS BESAR ISI & METODE & $\begin{array}{l}\text { MEDIA \& } \\
\text { ALAT }\end{array}$ \\
\hline \multicolumn{4}{|l|}{ PENDAHULUAN } \\
\hline Deskripsi singkat isi & $\begin{array}{l}\text { Lingkup pelajaran ini adalah } \\
\text { perbandingan, skala, jarak, } \\
\text { kecepatan dan waktu }\end{array}$ & Ceramah & - \\
\hline Relevansi dan manfaat & $\begin{array}{l}\text { Terdapat benda sehari-hari yang } \\
\text { yang berkaitan dengan perbandingan } \\
\text { skala, jarak, kecepatan dan waktu } \\
\text { dalam kehidupan sehari-hari }\end{array}$ & $\begin{array}{l}\text { Picture and } \\
\text { picture }\end{array}$ & - \\
\hline $\begin{array}{l}\text { Tujuan Instruksional } \\
\text { Khusus (TIK) }\end{array}$ & $\begin{array}{l}\text { Jika diberikan tes mengenai } \\
\text { perbandingan skala, jarak, kecepatan } \\
\text { dan waktu, maka siswa Kelas V SD } \\
\text { akan mampu menjawab dan } \\
\text { menyelesaikan secara jelas dan } \\
\text { tepat, minimal benar } 80 \%\end{array}$ & Ceramah & Modul \\
\hline \multicolumn{4}{|l|}{ TAHAP PENYAJIAN } \\
\hline Uraian & $\begin{array}{ll}\text { Penjelasan tentang : } \\
\text { - } & \text { Satuan jarak } \\
\text { - } & \text { Satuan waktu } \\
\text { - } & \text { Kecepatan } \\
\text { - } & \text { Skala }\end{array}$ & Jigsaw & $\begin{array}{l}\text { Modul dan } \\
\text { benda } \\
\text { konkret } \\
\text { sesuai } \\
\text { materi }\end{array}$ \\
\hline
\end{tabular}




\begin{tabular}{|c|c|c|c|}
\hline $\begin{array}{l}\text { URUTAN KEGIATAN } \\
\text { PEMBELAJARAN }\end{array}$ & GARIS BESAR ISI & METODE & $\begin{array}{l}\text { MEDIA \& } \\
\text { ALAT }\end{array}$ \\
\hline Contoh dan Non Contoh & $\begin{array}{l}\text { Contoh-contoh penerapan dari } \\
\text { satuan jarak, waktu kecepatan dan } \\
\text { skala }\end{array}$ & Jigsaw & $\begin{array}{l}\text { Benda } \\
\text { konkret } \\
\text { sesuai } \\
\text { materi }\end{array}$ \\
\hline Latihan & $\begin{array}{l}\text { Siswa SD Kelas V berlatih } \\
\text { mengerjakan soal berkaitan dengan } \\
\text { satuan jarak, waktu kecepatan dan } \\
\text { skala }\end{array}$ & Jigsaw & \\
\hline $\begin{array}{l}\text { Rangkuman } \\
\text { Glosarium } \\
\text { TAHAP PENUTUP }\end{array}$ & & & \\
\hline $\begin{array}{l}\text { Tes Formatif dan Umpan } \\
\text { Balik }\end{array}$ & $\begin{array}{l}\text { Mengidentifikasi kesulitan yang } \\
\text { dihadapi dalam mengerjakan tes }\end{array}$ & $\begin{array}{l}\text { Diskusi } \\
\text { variasi } \\
\text { dengan tanya } \\
\text { jawab }\end{array}$ & $\begin{array}{l}\text { Lembar soal } \\
\text { dalam } \\
\text { modul }\end{array}$ \\
\hline Tindak Lanjut & $\begin{array}{l}\text { - } \begin{array}{l}\text { Penjelasan kembali bagian- } \\
\text { bagian yang belum dimengerti } \\
\text { - } \\
\text { Pemberian latihan untuk } \\
\text { dikerjakan di rumah }\end{array}\end{array}$ & Ceramah & Modul \\
\hline
\end{tabular}

8. Mengembangkan Bahan Instruksional

Pendesain memilih Sistem Pembelajaran Tatap Muka (SPTM) dalam mengembangkan bahan instruksional berupa modul. Pada Sistem Pembelajaran Tatap Muka (SPTM), pengajar bertindak sebagai sumber belajar utama dan penyaji bahan instruksional yang dikompilasi. Pengajar harus mengisi apa yang tidak terdapat dalam bahan instruksional dan juga sebaliknya.Jadi, keduanya antara pengajar dan bahan instruksional kompilasi harus saling mengisi.

Pada kegaitan awal dalam mengembangkan bahan kompilasi instruksional, peneliti mengidentifikasi dan mengumpulkan berbagai bahan instruksional berupa analisis kebutuhan di sekolah melalui wawancara dan pengamatan, lalu proses menyusun strategi pembelajaran yang merupakan upaya untuk menjawab permasalahan-permasalahan yang diperoleh saat analisis instruksional. Selanjutnya peneliti merancang bahan instruksional ini dengan menghubungkan keterkaitan antara tujuan instruksional dengan strategi pembelajaran yang telah dibuat.

Peneliti mengembangkan bahan ajar berupa modul dan fokus pada materi pembelajaran matematika Sekolah Dasar Kelas V. Bahan ajar ini terdiri dari 8 BAB, yaitu pecahan; FPB dan KPK; perbandingan, skala, jarak dan waktu; sudut; bilangan pangkat dan akar bilangan; bangun datar; bangun ruang; statistika. Dengan sedemikian rupa, bahan ajar ini didesain oleh peneliti untuk memecahan permasalahan matematika dengan modifikasi warna dan ukuran simbol dan angka mengenai pelajaran Matematika sehingga siswa dapat terfasilitasi dengan baik.

Setelah proses bahan ajar telah didesain, selanjutnya peneliti membuat instrumen penilaian bahan ajar sebagai alat ukur kualitas atau uji kelayakan bahan ajar yang telah didesain. Aspek-aspek yang terdapat di dalam instrumen ini terdiri dari aspek konten (materi) atau bidang studi, aspek penyajian (media), aspek kebahasaan dan aspek desain grafis. Peneliti memodifikasi instrumen ini dari beberapa instrumen yang telah ada dan digunakan serta tambahan-tambahan dari beberapa sumber antara lain ahli media, materi disain dan bahasa dan satu orang guru SD Kelas V. 
Kemudian, nantinya peneliti membuat instrumen evaluasi formatif. "Evaluasi formatif dapat didefinisikan sebagai proses menyediakan, menganalisis, dan menggunakan data dan informasi untuk dijadikan dasar pengambilan keputusan dalam rangka meningkatkan kualitas produk atau program instruksional" (Suparman, 2014: 330). Evaluasi formatif adalah bagian integral dari proses pengembangan bahan instruksional. Instrumen evaluasi formatif ini meliputi kisi-kisi soal, soal-soal dan latihan, kunci jawaban, dan pedoman penskoran holistik, instrumen-instrumen ini disusun untuk mengetahui tingkat pencapaian tujuan instruksional setelah menggunakan media pembelajaran matematika Sekolah Dasar Kelas V. Peneliti telah mendiskusikannya dengan rekan sejawat, sehingga instrumen ini divalidasi oleh empat dosen matematika, tiga orang guru Kelas SD Kelas V. Produk bahan pembelajaran matematika Sekolah Dasar Kelas V ini mengalami beberapa kali perbaikan. Perbaikan tersebut berdasarkan masukan dari para ahli dan masukan validator. Serangkaian pengamatan tersebut sangat bermanfaat dalam perbaikan bahan pembelajaran secara muatan isi, desain buku, maupun dalam penyampaiannya.

\section{PEMBAHASAN}

Tahap pembuatan desain modul pembelajaran, peneliti mengadaptasi dari langkah-langkah model pengembangan instruksional yang dikembangkan oleh Suparman yang akhirnya menghasilkan bahan pembelajaran matematika SD Kelas V ini. Adapun tahapan tersebut adalah sebagai berikut.

a. Analisis Kebutuhan dan Menentukan Tujuan Instruksional Umum

Analisis kebutuhan siswa merupakan kegiatan awal pada proses pengembangan desain pembelajaran. Seperti sebuah pondasi, analisis kebutuhan dapat dijadikan pilar utama dalam proses analisis kebutuhan ini. Jika pada proses ini berjalan baik dan mendapatkan hasil konkrit di lapangan maka akan berjalan baik pula keseluruhan dalam proses pengembangan desain pembelajaran matematika SD Kelas V ini.

Pada tahap analisis kebutuhan penulis melakukan wawancara langsung kepada tiga orang guru Kelas V SD untuk mendapatkan informasi secara konkrit mengenai karakteristik siswa serta kompetensi yang diharapkan dapat dicapai oleh siswa yang duduk di Kelas V SD. Dari kegiatan wawancara tersebut beberapa dari narasumber mengatakan bahwa karakteristik siswa Kelas V SD masih sama dengan tingkatan kelas rendah Sekolah Dasar meskipun mereka berada di tingkatan kelas tinggi Sekolah Dasar, yakni masih pendiam dan pemalu, belum memiliki sikap disiplin dalam mengerjakan tugas, dan pola pikir siswa masih kekanak-kanakan. Saat proses pembelajaran, penulis mengamati serangkaian kegiatan yang terjadi di dalam kelas. Penulis melihat fakta bahwa siswa mudah bosan dan materi yang disampaikan terlalu sulit, beberapa siswa kesulitan memahami materi Matematika karena kesulitan memahami konsep matematika dan memahami simbol simbol dan angka matematika dalam operasi matematika. Siswa memiliki minat pada materi dan metode yang disenangi saja. Oleh karena itu, sangat dibutuhkan sebuah pembelajaran yang menarik dan modul yang mudah dimengerti oleh siswa. Selain itu sumber belajar yang sudah ada sangatlah terbatas, yaitu hanya ada buku paket yang dipinjamkan saat pelajaran berlangsung. Sejalan dengan hasil analaisis di atas berdasarkan hasil penelitian Kaufmann, 2003; Shalev, 2004 (dalam Santrock, 2009:248), para peneliti menemukan bahwa siswa yang memiliki kesulitan dalam perhitungan matematika sering mempunyai kekurangan neuropsikologis dan kognitif, termasuk prestasi yang buruk dalam mengelola ingatan, persepsi visual, dan kemampuan visual-spasial. Maka kami peneliti menyimpulkan bahwa untuk memenuhi kebutuhan siswa, kami dapat mengembangkan media pembelajaran dalam 
bentuk modul yang dikemas semenarik mungkin untuk menarik minat dan mempermudah siswa dalam proses belajar mengajar.

Dari kompetensi yang diharapkan, dirancang Tujuan Instruksional Umum (TIU) untuk menentukan kompetensi-kompetensi yang dapat dicapai oleh siswa di Kelas V SD sesuai dengan keinginan dan harapan dari pendidik Kelas V SD. Tujuan instruksional umum inilah dijadikan sebagai acuan untuk merangkai bahan pembelajaran sesuai dengan kompetensi-kompetensi yang diharapkan. Jadi, satu TIU disusun untuk mencakup keseluruhan proses pembelajaran matematika SD Kelas V.

Mulanya TIU yang disusun adalah "Jika diberikan soal latihan matematika mengenai pelajaran matematika Sekolah Dasar Kelas V, maka siswa Kelas V SD diharapkan mampu memahami dan mengerjakan dengan baik, dalam menyelesaikan soal-soal latihan maupun dalam pemecahan masalah berbentuk soal cerita dengan mandiri, cepat, dan minimal benar $80 \%$ ". Berdasar pada masukan dari narasumber maka TIU diubah menjadi "Jika diberikan soal latihan matematika mengenai pelajaran matematika Sekolah Dasar Kelas V, maka siswa Kelas V SD diharapkan mampu memahami dan mengerjakan dengan baik dalam menyelesaikan soal-soal latihan maupun dalam pemecahan masalah berbentuk soal cerita dengan kemampuan sendiri, cepat, dan minimal benar $80 \%$ meliputi materi Kelas V Sekolah Dasar serta meningkatnya antusiasme belajar, jujur, dan kreatif'.

b. Analisis Instruksional

Pada tahap analisis instruksional, peneliti merangkai tahapan pencapaian kompetensi siswa Kelas V SD, mulai dari yang kompetensi yang paling mudah bagi siswa hingga kompetensi paling sulit. Nantinya tahapan-tahapan ini akan dimasukkan dalam bahan pembelajaran yang akan digunakan pada pembelajaran matematika SD Kelas V. Analisis instruksional menghasilkan sebuah peta kompetensi yang menunjukkan susunan subagian kompetensi yang paling dasar sampai kompetensi yang paling tinggi seperti yang dirumuskan dalam TIU.

Dalam proses pembuatan analisis instruksional sebaiknya memperhatikan strukturstruktur kompetensi, yang terdiri dari struktur hierarkis, struktur prosprosedural, struktur pengelompokkan, dan struktur kombinasi. Struktur-struktur ini akan memudahkan dalam penyusunan peta kompetensi yang akan dicapai siswa. Peneliti membuat sebuah peta kompetensi yang mencakup semua materi yang akan dibahas pada pembelajaran matematika SD Kelas V.

c. Identifikasi Perilaku Siswa SD Kelas V

Pembuatan identifikasi perilaku siswa dimaksudkan agar peta kompetensi sesuai dengan perilaku siswa SD Kelas V yang nyata. Apabila terdapat ketidaksesuaian antara tahapan-tahapan yang telah dibuat dengan perilaku siswa yang sesungguhnya maka segera dibuat perubahan pada peta kompetensi untuk segera disesuaikan.

Penulis mengamati perilaku siswa yang dapat dilihat dari hasil analisis kebutuhan yang telah diperoleh pada proses awal kegiatan pengembangan desain instruksional. Hasil dari analisis kebutuhan tersebut, kemudian perilaku dan karakteristik yang ditunjukkan oleh siswa Kelas V SD dirangkum oleh sehingga terbagi dalam tiga karakteristik, yaitu karakteristik dilihat dari segi fisik, karakteristik dilihat dari segi kecerdasan, dan karakteristik dilihat dari segi sosialemosional.

d. Tujuan Instruksional Khusus (TIK)

Tujuan instruksional khusus merupakan satu-satunya dasar dalam menyusun kisi-kisi tes dan alat untuk menguji validitas isi tes. Dalam menentukan isi pelajaran yang akan diajarkan, peneliti merumuskannya berdasarkan kompetensi dasar yang ada dalam TIK. Dapat dikatakan bahwa apa yang ingin dicapai telah disesuaikan dengan isi pelajaran yang akan diajarkan. 
Tujuan instruksional khusus merupakan sebuah penjabaran dari TIU. Perumusan TIK ini sangat tergantung pada TIU. Oleh karena itu, TIU harus dimatangkan secara isi. Untuk proses penelitian ini peneliti menyusun empat butir TIK yang masing-masing TIK berkaitan dengan TIU yang telah dibuat sehingga mendapatkan komposisi yang pas dan sesuai dengan hasil yang diharapkan.

e. Alat Penilaian Hasil Belajar

Selanjutnya, penulis membuat rancangan instrumen penilaian. Nantinya instrumen penilaian ini akan dijadikan acuan dalam menilai hasil kompetensi pada akhir pembelajaran matematika Kelas V SD. Suparman (2014: 230) menyatakan bahwa "alat penilaian dimaksudkan untuk mengukur kompetensi dalam kawasan taksonomi kognitif yang biasa disebut tes dalam bentuk tertulis atau tes lisan dan harus dijawab dengan tertulis atau lisan pula".

Rancangan instrumen yang dibuat oleh penulis berupa butir-butir soal yang akan diujikan pada proses akhir pembelajaran. Butir-butir soal yang dibuat penulis mengacu pada tabel spesifikasi tes yang komperehensif. Tabel strategi yang dibuat memperhatikan TIU dan TIK yang telah dibuat sebelumnya. Tabel spesifikasi ini juga memuat indikator-indikator pencapaian siswa dalam pembelajaran matematika SD Kelas V.

Dalam pembuatan tabel spesifikasi tes peneliti mengamati indikator-indikator umum yang telah disusun oleh Depdiknas untuk mata pelajaran matematika SD Kelas V yang kemudian disesuaikan dengan kompetensi-kompetensi yang diharapkan dapat dicapai oleh siswa Kelas V SD. Pada proses pengamatan belum tentu langsung menemukan hasil yang mutlak, pastinya dalam penyusunannya akan terdapat berbagai perubahan, seperti pada soal pilihan ganda yang harus ditulis secara berurutan. Masukan ini bermanfaat untuk pembuatan butir-butir soal nantinya.

f. Strategi Pembelajaran

Pada tahap selanjutnya, peneliti telah mempersiapkan strategi pembelajaran agar pembelajaran dapat berjalan secara terarah untuk keberhasilan tercapainya kompetensikompetensi siswa. Isi pembelajaran untuk setiap TIK yang telah dirancang sebelumnya bersama komponen lain seperti langkah-langkah kegiatan instruksional, metode, serta media dan alat instruksional akan tergambar dalam strategi instruksional. Dengan kata lain, saat penyusunan strategi instruksional, peneliti juga membuat daftar isi pembelajaran.

Dalam penyusunan strategi instruksional, penulis harus menguasai teknik dan metodemetode pembelajaran serta media pembelajaran yang akan digunakan. Nantinya metode dan media pembelajaran ini akan membantu proses penyampaian materi yang akan disampaikan kepada siswa. Namun yang terpenting adalah pemahaman konsep materi pembelajaran yang dilakukan di sekolah harus benar-benar diperhatikan oleh penulis.

Pembuatan strategi pembelajaran oleh penulis akan terasa sulit apabila penulis tidak memahami materi dan proses pembelajaran yang umumnya telah berlangsung di lapangan secara pasti. Strategi pembelajaran ini dibuat unuk menjawab permasalahan-permasalahan yang didapat saat analisis kebutuhan. Oleh karena itu, agar menghasilkan sebuah pembelajaran yang menarik dan bermakna bagi siswa perlu diperhatikan kesesuaian antara metode dan media pembelajaran dengan materi pembelajaran itu sendiri.

Strategi pembelajaran ini tersusun pada setiap masing-masing TIK dengan dasar TIU. Nantinya strategi pembelajaran ini akan digunakan pada proses pembelajaran di Kelas dengan adanya metode dan media pembelajaran serta alokasi waktu yang ada telah terencana dengan baik sehingga tergambar serangkaian proses pembelajaran. Pada mulanya, peneliti mengalokasikan waktu selama 40 menit. Namun, setelah mendapat masukan dari guru kelas 
alokasi waktu diubah menjadi 35 menit. Diharapkan setiap tahapan yang termuat di dalam strategi pembelajaran dan pembahasan dalam TIK dapat terlaksana dengan baik guna tercapainya kompetensi-kompetensi dalam TIU.

g. Mengembangkan Bahan Instruksional

Bahan pembelajaran merupakan sebuah produk yang akan dihasilkan dari proses pengembangan desain pembelajaran matematika Sekolah Dasar Kelas V. Bahan instruksional inilah yang isinya memuat materi-materi dan kegiatan penunjang pembelajaran lainnya berupa latihan tugas mandiri dan tugas kelompok guna tercapainya kompetensi-kompetensi siswa.

Dari segi muatan isi (materi), penulis menyusun bahan instruksional ini dengan memperhatikan antara TIU dan TIK hingga strategi instruksional yang telah disusun sebelumnya. Selain itu dalam pembuatan bahan instruksional, penulis mencari sumber referensi dari beberapa buku-buku sekolah dari penerbit lain. Dari segi desain atau tampilan bahan instruksional, penulis buat sedemikian rupa dan menarik background berwarna disertai gambar-gambar menarik. Hal ini bertujuan untuk memudahkan siswa memahami pembelajaran matematika dan siswa tidak merasa bosan saat proses pembelajaran berlangsung.

\section{SIMPULAN}

Bahan pembelajaran matematika Sekolah Dasar Kelas V dalam desain instruksional yang dihasilkan ini telah dikembangkan dengan model pengembangan instruksional M. Atwi Suparman, meliputi tahap definisi, tahap analisis dan pengembangan. Pada tahap definisi terdiri dari mengidentifikasi kebutuhan instruksional dan menulis tujuan instruksional umum, melakukan analisis instruksional, serta mengidentifikasi perilaku dan karakteristik awal siswa. Pada tahap berikutnya, yakni analisis dan pengembangan terdiri dari menulis tujuan instruksional umum, menulis alat penilaian hasil belajar, menyusun strategi instruksional, dan mengembangkan bahan instruksional. Rancang bangun ini belum sampai pada tahap terakhir dalam melaksanakan evaluasi formatif terdiri dari penelaahan oleh pakar dan revisi yang nantinya akan dilanjutkan pada penelitian selanjutnya. Adapun bentuk fisik dari modul yang telah kami kembangkan dapat diakses melalui https://drive.google.com/file/d/1zqXMVMA5f3c901NcNQye65rbfVrC5oLo/view?usp=sharing

\section{UCAPAN TERIMA KASIH}

1. Kepala Sekolah SDN di kecamatan Muara Gembong Kabupaten Bekasi, yang telah mengizinkan dalam penyebaran angket dan wawancara di sekolah.

2. Gita Faramida Fitria mahasiswa semester akhir yang membantu dalam menyebarkan angket dan mewawancarai guru dan siswa.

\section{DAFTAR RUJUKAN}


Azhari, B. (2017). Identifikasi Gangguan Belajar Dyscalcullia pada Siswa Madrasah Ibtidaiyah. Jurnal Al Khawarizmi, 1 (1): 60-74.

Aminah, Kurniawati, A., \& Riska, K. (2018). Analisis Kesulitan Siswa dalam Menyelesaikan Soal Cerita Matematika Topik Pecahan Ditinjau dari Gender. Jurnal Teori dan Aplikasi $\begin{array}{lllll}\text { Matematika, } & 2 & \text { (2): } & \text { 118-122. } & \text { Retrieved }\end{array}$ http://eprints.ums.ac.id/77713/1/NASKAH\%20PUBLIKASI.pdf

Kemendiknas. (2006). Permendiknas No.22 Tahun 2006 Tentang Standar Isi Satuan Pendidikan Dasar dan Menengah. Jakarta: Kemendiknas.

Nadiyah, S., Wijaya, F. Y., \& Hakim, A. R. (2019). Desain Komik Strip Matematika pada Materi Statistika untuk Kelas VI Tingkat Sekolah Dasar. JKPM (Jurnal Kajian Pendidikan Matematika), 4(2): 135-146.

Nadun. (2017). Pengaruh Minat Belajar Siswa terhadap Hasil Belajar Trigonometri. JKPM (Jurnal Kajian Pendidikan Matematika), 3(1): 67-76.

Subini, N. (2012). Mengatasi Kesulitan Belajar pada Anak. Jogjakarta: Javalitera

Suparman, A. (2014). Desain Intruksional Modern Panduan Para Pengajar \& Invator Pendidikan. Jakarta: Erlangga.

Okezone (online). (2018). (https://news.okezone.com/read/2018/11/12/65/1976537/indonesiagawat-darurat-matematika). Diakses pada tanggal 10 Oktober 2019 pukul 21.30 WIB.

Patricia, F.A., \& Zamzam, K.F. (2019). Diskalkulia (Kesulitan Matematika) Berdasarkan Gender pada Siswa Sekolah Dasar di Kota Malang. AKSIOMA: Jurnal Program Studi Pendidikan Matematika, 8 (2): 288-297

Santrock, J.W. (2009). Psikologi Pendidikan. Jakarta: Salemba Humanika.

Utami, Y \& Nurfitriyani, M. (2017). Pengembangan LKS dalam Pembelajaran Matematika untuk Peserta Didik Tunagrahita. Jurnal Pendidikan Matematika. 3(1): 48. 
288 Karim, Purnama, \& Wiratomo.

JKPM (Jurnal Kajian Pendidikan Matematika) Vol.5, No.2 (2020) 